BARTŁOMIEJ MUSAJEW

Uniwersytet Jagielloński

b.musajew@gmail.com

\title{
PARADOKS WIECZNOŚCI I PRZEMIJANIA: DOŚWIADCZENIE CZASU W THAT IN ALEPPO ONCE... VLADIMIRA NABOKOVA ORAZ W JEGO POLSKICH PRZEKŁADACH
}

\begin{abstract}
The Paradox of Eternity and Evanescence: The Experience of Time in Vladimir Nabokov's That in Aleppo Once... and Its Polish Translations

Nabokov's definition of art is based on a paradox. The eternization of evanescent beauty annihilates it; by annihilating beauty, art annihilates itself. Even though there may exist a transcendent order, we can only access it in an indirect way, limited by time and ego. This paradox is strongly inscribed in the structure of That in Aleppo Once..., whose narrator is entangled in this circular dynamics between eternity and evanescence, creation and autodestruction. Only on the level of the author and the reader, i.e. on the level transcendent in relation to the fictional world, is there a possibility of passing from egocentric narratorial perspective to intersubjective space of language. In translation, this space has to be organized according to different rules. This is visible in two different Polish translations. In hers Teresa Truszkowska slightly reduces the narrator's obsession as a result of a more rationalizing interpretation; Leszek Engelking on the other hand, sometimes even emphasizes this obsession.
\end{abstract}

Key words: translation, short story, narrative, Nabokov, tense, time

Słowa klucze: przekład, opowiadanie, narracja, Nabokov, czas 
W wykładzie o Kafce Nabokov definiuje sztukę w następujący sposób: „«Piękno plus litość» - oto najtrafniejsza definicja sztuki. Tam, gdzie jest piękno, musi być i żal, z tej prostej przyczyny, że piękno musi umrzeć; piękno zawsze umiera, indywidualny styl umiera wraz z materią, cały świat umiera wraz z jednostką" (Nabokov 2000: 326). Jak można wywnioskować z powyższej definicji, sztuka wynika z żalu wywołanego przemijaniem piękna. Piękno zatem, którym zainteresowana jest sztuka, nie może być sprowadzone do pozaczasowego ideału. Piękno, o którym pisze Nabokov, zawiera się w czasie, a więc jest ono zawsze własnością jakiegoś momentu i musi wraz z tym momentem przeminąć. Gdyby piękno od tego momentu oddzielić, przestałoby być pięknem, a byłoby po prostu abstrakcyjną wartością. W tym pozornie prostym stwierdzeniu tkwi paradoks ściśle wpisany w twórczość pisarza. Paradoks ten dotyczy ontologicznego statusu piękna, czyli też ontologicznego statusu sztuki, której piękno jest częścią składową. Piękno wyrwane ze swojego czasowego kontekstu przestaje być pięknem, a więc przestaje istnieć - jak pisze sam Nabokov, „piękno musi umrzeć”, nie może zatem istnieć wiecznie. Sztuka, która uwiecznia piękno, jednocześnie je unicestwia. A unicestwiając piękno i żal związany z jego przemijaniem, unicestwia też siebie, ponieważ według tej definicji sztuka nie może istnieć bez piękna i żalu. Kreację można uznać za akt autodestrukcyjny. Przemijanie zyskuje zarazem status wieczności, a wieczność staje się przemijaniem. Ten cyrkularny ruch autodestrukcyjnej kreacji/twórczej autodestrukcji i wiecznego przemijania/ulotnej wieczności jest ściśle wpisany w strukturę językową i narracyjną opowiadania That in Aleppo Once..., którego wersja oryginalna oraz polskie przekłady autorstwa Leszka Engelkinga i Teresy Truszkowskiej są przedmiotem rozważań w niniejszym artykule.

Aby zrozumieć, jak pisarz wykorzystywał, a jednocześnie próbował przekroczyć wspominaną cyrkularną strukturę sztuki, należy przyjrzeć się bliżej jego rozumieniu artystycznej inspiracji. W twórczości Nabokova jest ona integralnym elementem nie tylko procesu twórczego, ale również gotowego dzieła. Świadczą o tym zarówno częste elementy metafikcyjne i intertekstualne, jak i uczynienie aktu tworzenia (często nieudanego lub tylko potencjalnego) jednym z motywów dominujących. Najdokładniejszą definicję artystycznej inspiracji Nabokov podaje w Wykładach o literaturze:

W moim przykładzie [niekontrolowanego wspomnienia wywołanego wrażeniem zmysłowym - B.M.] pamięć grała zasadniczą, choć nieuświadomioną 
rolę i wszystko zależało od idealnego stopienia przeszłości i teraźniejszości. W natchnieniu geniusza występuje trzeci składnik: jest tam przeszłość, teraźniejszość i przyszłość (wasza książka), które pojawiają się w jednym przebłysku, a zatem geniusz postrzega pełny, zamknięty krąg czasu, co oznacza ni mniej, ni więcej tylko tyle, że czas przestaje dlań istnieć. Jest to złożone doznanie, wrażenie, że cały wszechświat wnika w ciebie i że ty rozpuszczasz się całkowicie w otaczającym cię wszechświecie. Nagle walą się mury więzienia, w którym zamknięte jest ego, i do środka wdziera się nonego, żeby uwolnić więźnia - a tymczasem ten już tańczy na swobodzie.

Język rosyjski, który jest skądinąd stosunkowo ubogi w terminy abstrakcyjne, dostarcza definicji dwóch rodzajów natchnienia, inspiracji: wostorg i wdochnowienije, co można sparafrazować jako „uniesienie” (rapture) i „odzyskanie" (recapture). Różnica między nimi tkwi głównie w temperaturze: pierwsze jest gorące i krótkotrwałe, drugie chłodne i rozciągnięte w czasie. Rodzaj natchnienia, o którym mówiłem do tej pory, to czysty płomień wostorga, wstępne uniesienie, w którym nie ma gdzieś w perspektywie uświadomionego celu, ale które jest niesłychanie ważne dla powiązania procesu rozbijania dawnego świata z procesem budowania nowego. Kiedy rzecz dojrzeje i pisarz zasiądzie do praktycznego komponowania swej książki, będzie polegał na tym drugim, spokojnym rodzaju natchnienia, czyli na wdochnowieniju, zaufanym partnerze, który pomoże mu odzyskać, uchwycić powtórnie elementy rozbitego świata i odtworzyć go w nowej postaci (Nabokov 2000: 478).

Fragment ten, mimo że pochodzi z tekstu natury dyskursywnej, obrazuje podstawowy problem, z jakim mierzy się sztuka: wyrażenie niewyrażalnego. Jest on skonstruowany na podstawie wzajemnie się wykluczających metafor. Domknięcie kręgu czasu, zjednoczenie przeszłości, teraźniejszości i przyszłości oznacza również unicestwienie czasu. Zamknięty krąg oznacza wolność. Jednocześnie unicestwienie czasu to tylko przebłysk, a więc moment ściśle osadzony w czasie. Rozrost ego do rozmiarów wszechświata oznacza również rozpuszczenie się ego we wszechświecie. Mury więzienia się walą i ego ucieka, a jednocześnie do środka tego więzienia (które nie może być więzieniem, skoro nie istnieją jego mury) wkracza nonego - wydaje się więc, że ego nie może się rozrosnąć do rozmiarów wszechświata, ponieważ w pewnym punkcie tego wszechświata istniało więzienie, z którego ego uciekło i gdzie go już nie ma. W procesie tworzenia niezbędne jest rozbicie świata w momencie „uniesienia” oraz zbudowanie nowego świata z elementów świata rozbitego w procesie „odzyskania”. Problem jednak w tym, że proces wdochnowienija, „,chłodnej inspiracji”, nigdy nie będzie w stanie pozbierać elementów wostorga, czyli ,gorącej inspiracji”, ponieważ 
te muszą ostygnąć, żeby w ogóle doszło do procesu tworzenia. Można więc powiedzieć, że stworzenie świata polega na podwójnym zniszczeniu: najpierw $\mathrm{w}$ procesie pierwotnego natchnienia, a następnie w samym akcie pisania. Jasno widzimy w tym fragmencie wspomnianą skomplikowaną dynamikę między tworzeniem a destrukcją i przemijaniem a wiecznością.

$\mathrm{Z}$ tego fragmentu można wywnioskować, że istnieje rzeczywistość przekraczająca ludzką świadomość, ale człowiek nie ma do niej bezpośredniego dostępu: doświadczenie wieczności musi być ściśle osadzone w czasie; transcendentny porządek, którego się doświadczyło, musi zostać zniszczony. A jednak doświadczenie to, według Nabokova, może zostać choć częściowo przekazane w sztuce. Nie da się go opisać bezpośrednio. Taki opis mnożyłby tylko wykluczające się metafory albo, co gorsza, zmieniłby się w moralistyczne kazanie. Doświadczenie transcendencji musi więc, z poszanowaniem wszystkich paradoksów, zostać wpisane w tkankę dzieła, w jego strukturę i styl, a wokół tych dwu pojęć osnuł pisarz swoje wykłady. Nabokov wykorzystuje fakt, że autor i odbiorca dzieła literackiego są, w przeciwieństwie do postaci i narratora, poza obrębem fikcyjnego świata, to jest ich rzeczywistość stanowi rzeczywistość transcendentną wobec tego świata ${ }^{1}$.

Pora skupić się na strukturze omawianego tekstu. That in Aleppo Once... to opowiadanie w formie listu. Narrator, a jednocześnie główny bohater opowiadanych zdarzeń, kieruje prośbę do $\mathrm{V}^{2}$, prawdopodobnie uznanego rosyjskiego pisarza, aby ten rozjaśnił jego przeszłość ,,przez pryzmat [swojej] sztuki” (523)3. W następnym akapicie jednak posyła tę sztukę „do diabła”, stwierdzając, że jest „obrzydliwie nieszczęśliwy” (523). Narrator prosi V., aby ten nie umieszczał słowa Aleppo w tytule. Nie trzeba wspominać, że ta prośba nie zostaje wysłuchana. Tytuł pochodzi z ostatniego monologu Otella, który po zabiciu żony ${ }^{4}$ prosi zebranych, by po jego śmierci pamiętali

1 Metafizyczne implikacje tego faktu szczegółowo omawia wielu krytyków. Najważniejszym z nich jest Brian Boyd (1990, 1991, 2001). Pisze o nich również autor jednego z tłumaczeń, Leszek Engelking (2011).

${ }^{2}$ Można to potraktować jako pułapkę na nieostrożnego czytelnika, który zbyt pochopnie utożsamiałby odbiorcę listu z rzeczywistym autorem. Warto zauważyć, że ta pułapka zostaje wzmocniona w tłumaczeniu Truszkowskiej i rozbrojona w tłumaczeniu Engelkinga. Pierwsza wersja zachowuje nieistniejącą w polskim alfabecie literę V, co automatycznie nasuwa skojarzenie z Vladimirem Nabokovem. Engelking, świadomy zasad transliteracji $\mathrm{z}$ języka rosyjskiego, zmienia adresata listu na W.

3 Wszystkie cytaty z opowiadania wg Nabokov 2009. Numer w nawiasie oznacza stronę.

${ }^{4}$ Alexander Drescher w A Reading of Nabokov's 'That in Aleppo Once...' idzie o krok dalej i na podstawie sugestii zawartych w opowiadaniu stawia tezę, że to narrator opowiadania zabił swoją żonę. 
o heroicznym czynie w Aleppo: zabiciu wrogiego Turka. Sam morderczy cios Otello obrazuje na sobie, łącząc rzeczywistość swojego przeszłego czynu z teraźniejszą tragedią i tym samym odbierając sobie życie. Nadanie tytułu nie oznacza jednak, że V. jest autorem; jest on jedynie adresatem, jedną z postaci opowiadania i być może wydawcą listu.

W opowiadaniu można wyróżnić trzy główne płaszczyzny czasowe: czas teraźniejszy, to jest pobyt narratora w Ameryce; traumatyczny czas niedalekiej przeszłości, to jest czas pobytu narratora w okupowanej przez nazistów Francji, w którym zawiera się okres zazdrości narratora wobec jego żony, tułaczka po Francji, perypetie związane z próbą zdobycia wiz oraz niewyjaśnione odejście żony; szczęśliwy czas odległej przeszłości, to jest okres dzieciństwa i młodości spędzony w Rosji. Sytuację komunikacyjną również można podzielić na trzy poziomy: list po publikacji, dostępny dla potencjalnie nieskończonej liczby odbiorców i opatrzony tytułem; list przed publikacją, którego jedynym adresatem jest V.; a także komunikację między postaciami, włączając $\mathrm{w}$ to narratora będącego równocześnie bohaterem. Narrator wielokrotnie używa czasowników sygnalizujących mowę zależną (np. she said) ${ }^{5}$, sprowadzając tym samym narrację na poziom określony przez Gérarda Genette'a jako metadegetyczny (Genette 2007: 237). Przez redukcję swojej przeszłości do słów innych postaci chce osiągnąć dwa cele. Po pierwsze, odpycha od siebie odpowiedzialność za własne czyny i słowa. Za przykład można podać (prawdopodobnie) uduszonego przez narratora psa. Sam narrator nigdy się do tego czynu nie przyznaje. Przytacza on tylko słowa swojej żony, a sam zarzeka się, że nigdy żadnego psa nie było. Kiedy kwestia psa powraca, znowu zostaje sprowadzona do mowy zależnej, tym razem nawet drugiego stopnia: narrator odwołuje się do słów starszej kobiety, która słyszała o tym czynie od żony narratora. Po drugie, narrator próbuje nadać przeszłym zdarzeniom status niewinnej fikcji. Poza mową zależną wykorzystuje też inne techniki służące temu samemu zamiarowi: nawiązania intertekstualne ${ }^{6}$, elementy metafikcyjne, np. odwołanie do utartych

5 Sam tytuł jest zdaniem podrzędnym w mowie zależnej: And say besides, that in Aleppo once... (Othello 5.2.348). Do tego tytuł jest ujęty w cudzysłów, a więc mamy tu do czynienia z fikcją drugiego stopnia: historią opowiadaną przez bohatera innego dzieła literackiego. Truszkowska zneutralizowała ten efekt, pomijając spójnik.

${ }^{6}$ Głównym nawiązaniem jest oczywiście nawiązanie do Otella. Poza tym narrator przedstawia swoje życie przez pryzmat twórczości Czechowa, biografii Puszkina oraz opisuje przestrzeń za pomocą aluzji do Baśni z tysiąca i jednej nocy, która, jak wiadomo, składa się z fikcji wewnątrz fikcji. Gdyby przyjąć wersję zabójstwa, można by również stwierdzić, że 
schematów literackich, a także techniki obrazowania redukujące realność wspomnień przez zmniejszenie ich wyrazistości, a więc np. słownictwo związane z ograniczeniem widoczności (np. nebulous, hazy, mist). Widać tu napięcie między dwoma współzależnymi, a zarazem wykluczającymi się dążeniami: dążeniem do jasności, do transcendentnej prawdy sztuki (publikacja opowiadania powoduje obiektywizację cierpienia narratora czy raczej oddanie go w intersubiektywnej przestrzeni języka uwolnionej od ograniczonej perspektywy), i zredukowaniem przeszłości do fikcji, czystym eskapizmem. Można więc powiedzieć, że - jak Otello - bohater dokonuje podwójnego samobójstwa: samobójstwa przez autoiluzję oraz samobójstwa przez język, który obnaża fakt dezintegracji narratora. Nie wiemy, czy - jak Otello - bohater dokona również samobójstwa w sensie dosłownym.

Dążenie do zredukowania przeszłości do fikcji przynosi skutek przeciwny do zamierzonego. Przeszłość nabiera dla narratora bolesnej realności (dlatego jest „obrzydliwie nieszczęśliwy”), a jego teraźniejszość ulega odrealnieniu. Proces ten jest wpisany już w pierwsze zdania opowiadania, na pierwszy rzut oka stwierdzające po prostu fakt dotarcia narratora do Ameryki:

Drogi W.! Śpieszę Panu donieść między innymi, że jestem wreszcie tutaj, w tym kraju, do którego prowadziło mnie tyle zachodów słońca. Jedną z pierwszych osób, jakie ujrzałem, był nasz stary dobry Gleb Aleksandrowicz Giekko: posępnie przechodził przez Columbus Avenue w poszukiwaniu owej petit café $d u$ coin, której nigdy już nie odwiedzi żaden z nas trzech. Jak się zdaje, uważa on, że w ten czy inny sposób zdradza Pan naszą literaturę narodową... (509) ${ }^{7}$.

Warto zauważyć, jaką informację narrator postanowił przekazać adresatowi swojego listu w pierwszej kolejności: I am here, ,jestem tutaj”. To stwierdzenie pełni co najmniej trzy funkcje. Po pierwsze, informuje po prostu, że narrator dotarł do miejsca, które zarówno jemu, jak i adresatowi

mamy tu do czynienia z przeciwieństwem Baśni...: narrator, który już dokonał egzekucji żony, próbuje wyprzeć ten moment z pamięci, oddalić go w fikcję, tym samym go unicestwiając. Król zamordował już swoją niewierną żonę, a teraz opowiada historie, żeby odwlec moment przyjęcia odpowiedzialności.

7 DEAR V. - Among other things, this is to tell you that at last I am here, in the country whither so many sunsets have led. One of the first persons I saw was our good old Gleb Alexandrovich Gekko gloomily crossing Columbus Avenue in quest of the petit cafe du coin which none of us three will ever visit again. He seemed to think that somehow or other you were betraying our national literature... (Nabokov 2010: 641 [wyróżn. B.M.]). 
jest znane (czytelnik może wywnioskować, że mowa o Ameryce). Po drugie, otwarcie odwołuje się do sytuacji komunikacyjnej i tym samym określa punkt odniesienia (można to zrozumieć w następujący sposób: piszę list teraz, z tego miejsca, a więc wszystko, o czym będę pisał w czasie przeszłym, stało się przed tym momentem). Po trzecie, oznajmiając $I$ am here, narrator próbuje przekonać siebie i adresata, że istnieje integralnie, w jednym czasie i miejscu jako jednolite ego. Jest to jednak złudne pocieszenie, ponieważ dezintegracja narratora jest zbyt daleko posunięta; te trzy fundamentalne słowa w przypadku narratora stanowią tylko kolejny przejaw napięcia między autoiluzją a potrzebą osiągnięcia prawdy.

O ile przekład słów I am here nie daje tłumaczowi wielkiego wyboru, o tyle kolejne dwa czasowniki już tak. Najpierw zwróćmy uwagę na czasownik see. Można go rozumieć na dwa sposoby: jako „ujrzeć” i jako „spotkać”, i obie wersje pojawiają się w przekładach. Decyzja tłumacza ma tu poważne konsekwencje, o ile bowiem ,spotkanie” (wersja Truszkowskiej) jest interpretacją zdroworozsądkową, o tyle „ujrzenie” (wersja Engelkinga) podkreśla dezintegrację narratora. Skoro narrator znajduje się (a przynajmniej tak twierdzi) w Nowym Jorku, raczej nikłe jest prawdopodobieństwo, że przed zobaczeniem znajomego nie widział tłumów ludzi - tym bardziej że narrator spotkał Giekko gdzieś w samym mieście, a nie natychmiast po przybyciu do Ameryki. Możliwe więc, że Giekko jest wyłącznie widmem z przeszłości, które ma jednak większą realność dla bohatera niż jego otoczenie (zauważmy zresztą francuskie wtrącenie, sugerujące, że kafejka poszukiwana przez Giekko znajduje się w Paryżu, który obaj opuścili; chodziłoby więc o szukanie jej nie w przestrzeni, ale w czasie ${ }^{8}$ ). Jak się okaże, później narrator wspomina o ,zielonej próżni Central Parku”, gdzie przeszłość „,wpełza” na narratora (Nabokov 2009: 513). Mamy tu do czynienia z odwróconym porządkiem: teraźniejszość jest próżnią, a przeszłość staje się niemal cielesna.

Istnieje również inna możliwa interpretacja: narrator opisuje Amerykę ze swojej fantazji albo snu, w którym rzeczywiście dysponuje tylko znajomymi twarzami. Mając to na uwadze, wróćmy na chwilę do poprzedniego

8 Zarówno Giekko, jak i narrator stanowią przykład obu rodzajów inspiracji działających w odizolowaniu. Giekko reprezentuje wdochnowienije bez wostorga. Poszukuje francuskiej kafejki w sposób czysto intelektualny i dlatego nigdy jej nie znajdzie, może co najwyżej sprowadzić swoje wspomnienia do czystej generalizacji (mówi zresztą o tworze tak abstrakcyjnym jak literatura narodowa). Narrator reprezentuje wostorg bez wdochnowienija, tj. niemożliwość uwolnienia się od bolesnej realności wspomnień, niemożliwość intelektualnego oderwania się. Górny wierzchołek trójkąta stanowi W., prawdziwy artysta, który łączy oba rodzaje inspiracji. 
zdania, a dokładniej do słów whither so many sunsets have led. Angielski czas teraźniejszy uprzedni wyraźnie sugeruje, że opisana przeszła sytuacja ma związek z sytuacją teraźniejszą. Związek ten można oczywiście rozumieć zupełnie zdroworozsądkowo: proces podróży (teraz już zakończony) doprowadził do tego, że narrator w tym momencie znajduje się w Ameryce. I rzeczywiście, na taką interpretację wskazuje tryb dokonany użyty przez Truszkowską (,przywiodło”). Istnieje jednak inna możliwość: proces był (a może dalej jest) powtarzany cyklicznie, jak zachód słońca. Mowa więc byłaby tu o pewnym obsesyjnym śnie, przedstawionym w końcu przez narratora drugiej osobie. Taka interpretacja jest możliwa w przypadku thumaczenia Engelkinga (,prowadziło”), chociaż brak odpowiednika aspektu uprzedniego w języku polskim powoduje, że związek przeszłości z teraźniejszością nie jest tak wyraźny.

Ten sam problem widzimy przy tłumaczeniu słów he seemed. Engelking poprzez czas teraźniejszy (,Jak się zdaje, uważa on...”) nawiązuje do czasu narracji. Narrator jak gdyby próbował sobie przypomnieć reakcję Giekko, ale też starał się ją odnieść do subiektywnego odczucia (co sugeruje brak pewności). Jednocześnie tworzy to wrażenie obecności Giekko w teraźniejszym momencie - albo w postaci wspomnienia, albo w postaci widma z przeszłości. Interpretacja ta nie jest możliwa w drugiej, bardziej racjonalnej wersji, która jasno lokuje opinię Giekko w przeszłości („Chyba uważał...”).

Problem z tłumaczeniem czasu i aspektu widoczny jest również w innym kluczowym miejscu:

Zgnieceni i wytrzęsieni w fali apokaliptycznego exodusu, czekając na pozarozkładowe pociągi (...) ciągle uciekaliśmy; a im dalej uciekaliśmy, tym oczywistszy stawał się fakt, że gna nas (...) coś potwornego i niewyczuwalnego - bezczasowa i bezkształtna masa odwiecznej grozy, która wciąż wpełza na mnie od tyłu nawet tutaj, w zielonej próżni Central Parku (512-513) ${ }^{9}$.

Przytoczone zdanie składa się z trzech części. Pierwsza, opisująca proces ucieczki, kończy się czasownikiem w czasie przeszłym prostym, który sam w sobie nie precyzuje aspektu: fled równie dobrze może oznaczać uciekliśmy, jak i uciekaliśmy. Można powiedzieć, że pierwsza część zdania daje pewną

${ }^{9}$ Crushed and jolted amid the apocalyptic exodus, waiting for unscheduled trains (...) we fled; and the farther we fled, the clearer it became that what was driving us on was (...) something monstrous and impalpable, a timeless and faceless mass of immemorial horror that still keeps coming at me from behind even here, in the green vacuum of Central Park (Nabokov 2010: 643 [wyróżn. B.M.]). 
nadzieję na szczęśliwe zakończenie, a druga część tę nadzieję odbiera, ponieważ przysłówek farther jednoznacznie określa aspekt czasownika fled jako niedokonany. Okazuje się dalej, że narrator wciąż ucieka przed tym czymś i, co więcej, to coś nabiera większej realności niż tutaj narratora. Zdanie to wyraża również proces, który stanowi podstawę całego opowiadania: próba wyparcia przeszłości, czyli zamknięcia jej w aspekcie dokonanym, nie przynosi skutku; co więcej, przeszłość ostatecznie dominuje nad narratorem także w teraźniejszości. Pierwszy etap w thumaczeniu zlewa się z drugim, język polski bowiem wymaga doprecyzowania aspektu, a w tym kontekście, ze względu na drugą część zdania, aspekt dokonany jest wykluczony.

O napięciu między teraźniejszością a przeszłością świadczy również struktura czasowa zdania:

znamy przecież wszyscy tę oślepiającą eksplozję, spowodowaną głupim podniesieniem laleczki z podłogi skrupulatnie porzuconego domu: żołnierz, który ją podnosi, nie słyszy nic, dla niego jedynie ekstatycznie, bezdźwięcznie, nie znając żadnych granic rozrasta się to, co przez całe jego życie było malutkim jak łepek szpilki punkcikiem światła w mrocznym jądrze jego istnienia $(510)^{10}$.

Narrator najpierw opisuje w czasie przeszłym początek swojego uczucia do żony. Następnie, jak gdyby przerażony tym wspomnieniem, próbuje obrócić je w nieszkodliwą prawdę uniwersalną (we all know), wyrażoną w czasie teraźniejszym. A jednak automatycznie ilustruje tę prawdę przykładem żołnierza, który, jak już wiemy, symbolizuje to coś, od czego narrator nie może się uwolnić: mimo próby neutralizowania przeszłości przez uniwersalizację przeszłość wciąż daje o sobie znać. I rzeczywiście, przy ostatnim czasowniku przeszłość ponownie wydostaje się na powierzchnię za pośrednictwem czasu zaprzeszłego - nieuzasadnionego wobec reszty zdania w czasie teraźniejszym. Czas teraźniejszy był tylko fasadą, która miała stwarzać pozór ugruntowania w rzeczywistości. Pod rzeczywistością jednak nieustannie ,pełznie” przeszłość. Ilustruje to następne zdanie:

W istocie przyczyną, dla której kojarzymy śmierć z niebiosami, jest to, że widzialny firmament, zwłaszcza nocą (nad naszym zaciemnionym Paryżem

${ }^{10}$ and of course we all know of that blinding blast which is caused by merely picking up a small doll from the floor of a carefully abandoned house: the soldier involved hears nothing; for him it is but an ecstatic soundless and boundless expansion of what had been during his life a pinpoint of light in the dark center of his being (Nabokov 2010: 642 [wyróżn. B.M.]). 


\section{$\mathrm{z}$ wymizerowanymi łukami na Boulevard Exelmans i nieustannym alpej-} skim bulgotaniem wyludnionych ustępów) jest najstosowniejszym symbolem owego potężnego milczącego wybuchu (510).

Uniwersalizująca metafora śmierci nagle zostaje przerwana dość konkretnym i przyziemnym obrazem Paryża i paryskich ustępów. Co więcej, narrator nie może przerwać nieustannego bulgotu tych ustępów, mimo że teoretycznie uciekł już z Paryża. Metaforyczny, uniwersalny wybuch jest, wprost przeciwnie, ,milczący”. Mamy tu do czynienia z trawestacją doświadczenia wostorga, które normalnie w pewien sposób pozwala artyście wyjść poza obręb świadomości ograniczonej czasem. Tutaj ów patologiczny wostorg, ta „oślepiająca eksplozja”, jest wyłącznie kolejną oznaką obsesji narratora na punkcie jego przeszłości. Czas zaprzeszły ze względu na właściwości współczesnej polszczyzny zostaje utracony w tłumaczeniu.

O ile w poprzednim przykładzie tłumacz nie miał dużego wyboru, o tyle tutaj musiał podjąć decyzję:

Ach, za pierwszym razem była zbyt zmęczona, żeby protestować, później nie protestowała, ponieważ była przekonana, że odwróciłem się od niej; najwyraźniej uznała, że takie wyjaśnienia będą czymś w rodzaju nagrody pocieszenia, a nie bzdurą i męką, którą były w istocie. Ciągnęło się to bez końca, raz po raz dostawała ataków nerwowych... (517) ${ }^{11}$.

Narrator opisuje teraźniejszość swojej zazdrości przy użyciu słowa eons, co oczywiście jest hiperbolą oddającą subiektywne postrzeganie przez niego czasu. Co więcej, narrator pisze, że nie tylko cały okres trwał eony, ale i pojedyncze momenty tych eonów (every now and then) również trwały eony. Po raz kolejny mamy do czynienia z patologicznym doświadczeniem wieczności. Narrator w swoim egocentrycznym zaślepieniu nie potrafi nabrać intelektualnego dystansu do przeżytych doświadczeń. Dla niego ulotny moment cierpienia nabiera statusu wieczności, a wieczność przemijania powtarza się w nieskończonej iteracji (więcej o aspekcie iteratywnym pisze Genette, 2007: 111-162). Doświadczenie narratora jest więc nie tylko bolesne, ale też monotonne. Wieczność funkcjonuje na trzech poziomach: na poziomie opowiadanej historii, na poziomie narracji i na poziomie języka, w którym

${ }^{11} \mathrm{Oh}$, the first time she had been too tired to mind, and the next had not minded because she was sure I had deserted her; and she apparently considered that such explanations ought to be a kind of consolation prize for me instead of the nonsense and agony they really were. It went on like that for eons, she breaking down every now and then... (Nabokov 2010: 647 [wyróżn. B.M.]). 
to zdanie zostaje utrwalone. Widzimy tu działanie paradoksu opisanego na początku artykułu: przemijanie nabiera statusu wieczności, a przez utrwalenie ulega autodestrukcji w intersubiektywnej przestrzeni języka. Jednocześnie narrator próbuje doprowadzić do autodestrukcji swoje przeszłe ,ja”, tym samym wywołując własną dezintegrację. Jeśli chodzi o tłumaczenie Engelkinga, wyrażenie „bez końca” co prawda oddaje wieczny wymiar przemijania, ale neutralizuje aspekt monotonnej iteracji tej wieczności, skupiając się raczej na ciągłości. Eon to mimo wszystko skończony przedział czasu, choć z perspektywy człowieka zdaje się wiecznością. Przekład Truszkowskiej (,całe eony”) jest wierny, ale nieidiomatyczny, co w pewnym stopniu podkreśla doświadczenie narratora bardziej niż oryginał.

Jak widzieliśmy, całe opowiadanie jest oparte na procesie dezintegracji narratora. Im bardziej narrator chciałby unicestwić swoje wspomnienia, tym większej realności nabierają; im większej realności nabierają, tym boleśniej narrator uzmysławia sobie, że żyje w czasie, który już minął. Dlatego tkwi on w zawieszeniu: przeszłość przeżywa jako wieczność, ale jest też świadomy tego, że ta wieczność jest tak naprawdę tylko powtarzaniem tego, czego już nie ma. W ostatnim akapicie opowiadania narrator otwarcie poddaje się temu procesowi:

Do diabła z Pańską sztuką, jestem obrzydliwie nieszczęśliwy. A ona ciągle chodzi, idzie w jedną stronę, potem zawraca, tam gdzie na kamiennych płytach rozkłada się dla wysuszenia brązowe sieci i gdzie cętki odbitego od fal światła igrają na burcie przycumowanej do brzegu łodzi rybackiej $(523)^{12}$.

Narrator ostatecznie wypowiada się o swojej żonie w czasie teraźniejszym, nie będąc w stanie dłużej wypierać jej realności. Co więcej, powtarza się tu wspomniana struktura czasu: mamy trwanie podkreślone strukturą keeps on walking, ale mamy też iterację (to and fro). Takie zakończenie wzmacnia nieracjonalną interpretację czasu teraźniejszego uprzedniego z początku opowiadania. Engelking oddaje w przekładzie zarówno ciągłość („,ciągle chodzi”), jak i iteratywność (poprzez obrócenie wyrażenia to and fro w dwa czasowniki: ,idzie” i ,zawraca”). Dodatkowo podkreśla tę iteratywność, tłumacząc czasownik are spread jako „rozkłada się”, czyli jako czynność powtarzaną. Truszkowska oddaje frazę walks to and fro jako

${ }_{12}$ Curse your art, I am hideously unhappy. She keeps on walking to and fro where the brown nets are spread to dry on the hot stone slabs and the dappled light of the water plays on the side of a moored fishing boat (650 [wyróżn. B.M.]). 
„przechadza się”, sugerując okazjonalność raczej niż powtarzalność, co nie wyraża pełnego wymiaru cierpienia bohatera. Ponadto słowa are spread przełożone zostały jako „rozwieszono”, czyli jako jednorazowa czynność.

Jak widzimy, Nabokov umiejętnie wpisuje paradoks sztuki w strukturę opowiadania. Przemijanie dla narratora ma status wieczności. Narrator zdaje sobie sprawę, że jedynym rozwiązaniem jest autodestrukcja: albo autodestrukcja przez utrwalenie - a więc i unicestwienie - własnego cierpienia w intersubiektywnej rzeczywistości języka, albo autodestrukcja przez sprowadzenie swojej przeszłości do statusu fikcji. Tylko ten pierwszy sposób pozwala osiągnąć transcendencję sztuki, ale dopiero po oderwaniu listu od egocentrycznego umysłu narratora i oddaniu go czytelnikowi. Drugi sposób prowadzi do odrealniania narratora. Na podstawie przytoczonych fragmentów widać, że polskie przekłady osiągają różne efekty. U Truszkowskiej mamy łagodny efekt racjonalizacji (z wyjątkiem fragmentu o eonach). U Engelkinga większy nacisk jest położony na subiektywny stan narratora. Do wyborów dokonanych przez tłumaczy dochodzą też różnice między gramatyką obu języków. Wszystkie te czynniki sprawiają, że polskie wersje wyrażają trochę odmienne wizje świata: w świecie Truszkowskiej przez ciemną warstwę obsesji narratora prześwitują promienie racjonalnego rozumowania; u Engelkinga narrator nie ma takiego przywileju.

\section{Bibliografia}

\section{Literatura podmiotu}

Nabokov V. 1988. Gdy raz w Aleppo..., w: V. Nabokov, Opowiadania, przeł. T. Truszkowska, Kraków: Wydawnictwo Literackie, s. 163-174.

2009. Że gdy raz w Aleppo..., w: V. Nabokov, Kęs życia i inne opowiadania, przeł. L. Engelking. Warszawa: Warszawskie Wydawnictwo Literackie MUZA SA, s. 509-523.

2010. That in Aleppo Once..., w: V. Nabokov, Collected Stories, London: Penguin Books, s. 641-650.

Shakespeare W. 2003. Othello, Cambridge: Cambridge University Press. 


\section{Literatura przedmiotu}

Boyd B. 1990. Nabokov: The Russian Years, Princeton: Princeton University Press.

— 1991. Nabokov: The American Years, Princeton: Princeton University Press.

2001. Nabokov's Ada: The Place of Consciousness, Christchurch: Cybereditions.

Drescher A.N. A Reading of Nabokov's 'That in Aleppo Once...', Zembla,

https://www.libraries.psu.edu/nabokov/dresch1.htm (dostęp: 11.12.2015).

Engelking L. 2011. Chwyt metafizyczny. Vladimir Nabokov - estetyka z sankcja wyższej rzeczywistości, Łódź: Wydawnictwo Uniwersytetu Łódzkiego.

Genette G. 2007. Discours du récit, Paris: Éditions du Seuil.

Nabokov V. 2000. Wyktady o literaturze, przeł. Z. Batko, Warszawa: Warszawskie Wydawnictwo Literackie MUZA SA. 